\title{
Assessment of neutrophil / lymphocyte ratio in patients with myocardial bridge
}

\section{Miyokardiyal kas bandı olan hastalarda nötrofil / lenfosit oranının değerlendirilmesi}

Abdulkadir Yıldız, Mehmet Ata Akil, Fethullah Kayan, Murat Yüksel, Mehmet Zihni Bilik, Mustafa Oylumlu, Nihat Polat, Mesut Aydın, Halit Acet, Sait Alan

\begin{abstract}
Objective: Myocardial bridge (MB) is a congenital anomaly characterized by systolic narrowing of the epicardial coronary arterial segment while traveling in the myocardium. It is a benign entity but previous studies showed that the proximal portion is prone to an enhanced atherosclerosis. Neutrophil/lymphocyte ratio (NLR) is a sensitive marker of systemic inflammation used as a predictor for adverse cardiovascular outcomes in atherosclerotic heart disease. So in this study, we sought to evaluate the association between NLR and myocardial bridging.
\end{abstract}

Methods: A total of 172 patients (mean age: $50.8 \pm 11.5$ years, $77.3 \%$ men) with either angiographically proven MB or normal coronary arteries were included in the study. For the entire study population, hematologic parameters were measured using an automatic blood counter.

Results: The study population consisted of 71 patients with MB (mean age: $51.4 \pm 11.9$ years, $80.3 \%$ male) and 101 patients with normal coronary arteries (mean age: $50.5 \pm 11.3$ years, $75.2 \%$ male). There were no significant differences between groups regarding hemoglobin level, platelet count, glucose and creatinine. Compared to the control group, NLR was significantly higher in patients with $\mathrm{MB}(2.45 \pm 1.19$ vs. $1.72 \pm 0.48 ; \mathrm{p}<0.001)$. In ROC analysis, NLR > 1.82 predicted myocardial bridge presence with $70 \%$ sensitivity and $71 \%$ specificity (ROC area under curve: $0.733,95 \% \mathrm{Cl}$ : 0.654-0.811, $\mathrm{p}<0.001$ ).

Conclusion: Our study findings demonstrated that MB is associated with elevated NLR, which is used to assess inflammatory status of the body. J Clin Exp Invest 2014; 5 (1): 24-28

Key words: Inflammation, neutrophil/lymphocyte ratio, and myocardial bridge

\section{INTRODUCTION}

Myocardial bridge (MB) is a congenital, usually benign coronary anomaly, in which a segment of major epicardial coronary artery courses through myocardium [1,2]. Angiographic frequency of MB in adults varies substantially in different populations,

\section{ÖZET}

Amaç: Miyokardiyal kas bandı miyokart içinde seyreden epikardiyal koroner arterlerin sistolde daralması ile seyreden konjenital bir anomalidir. İyi huylu olmasına rağmen önceki çalışmalarda proksimal kesimlerin artmış ateroskleroza eğilimli olduğu gösterilmiştir. Nötrofil/lenfosit oranı (NLO) aterosklerotik kalp hastalıklarında kötü prognozu öngören sistemik enflamasyonun duyarlı bir belirtecidir. Biz bu çalışmada NLO ile miyokardiyal kas bandı arasında bir ilişki var olup olmadığını araştırmayı amaçladık.

Yöntemler: Anjiyografik olarak tespit edilmiş miyokardiyal kas bandı veya normal koroner arterleri olan 172 hasta (ortalama yaş: $50.8 \pm 11.5$ yıl, \%77.3 erkek) çalışmaya dahil edildi. Otomatik kan sayacı kullanılarak tüm hastaların hematolojik parametreleri ölçüldü.

Bulgular: Çalışma 71 miyokardiyal kas bandı (ortalama yaş: 51,4 $\pm 11,9$ yıl, \%80,3 erkek) ve 101 normal koroner arterleri (ortalama yaş: 50,5 \pm 11,3 yıl, \%75.2 erkek) olan hastadan oluşmaktaydı. Hemoglobin, trombosit sayısı, glukoz ve kreatinin açısından gruplar arasında fark saptanmadı. Kontrol grubuna göre miyokardiyal kas bandı grubunda NLO anlamlı olarak daha yüksekti $(2,45 \pm 1,19$ vs. $1,72 \pm 0,48 ; p<0,001)$. ROC analizinde, NLO > 1,82 miyokardiyal kas bandı varlığını $\% 70$ duyarlılık ve $\% 71$ özgüllükle öngörmüştür (ROC eğri altında kalan alan: 0.733, 95\% güvenlik aralığı: 0.654-0.811, p < 0.001).

Sonuç: Çalışmamız miyokardiyal kas bandının vücutta enflamatuar düzeyi gösteren yüksek NLO seviyeleri ile ilişkili olduğunu göstermiştir.

Anahtar kelimeler: İnflamasyon, nötrofil/lenfosit oranı, miyokardiyal kas bandı

reported to range from $0.83 \%$ to $7.5 \%$ [3-5]. Myocardial bridges are prone to be localized in the middistal segment of the left anterior descending (LAD) artery [3-6]. Although MBs are not usually clinically significant, some longer and thicker ones can cause myocardial ischemia, life-threatening rhythm distur- 
bances, acute coronary syndromes, or even sudden cardiac death [7-11].

Neutrophil/lymphocyte ratio (NLR) has recently proposed as a new prognostic marker [12-14]. The relationship between the NLR and a wide range of cardiovascular disorders has been shown in several studies [15]. Although intramural and distal portions of a bridged artery usually remain free from atherosclerosis, the proximal portion is prone to an enhanced atherosclerosis [16-18]. In the present study, we hypothesized that enhanced atherosclerosis proximal to bridged artery may be related with increased NLR. Therefore, we sought to measure NLR levels in patients with MB to assess the inflammatory status of the body.

\section{METHODS}

\section{Study Population}

Seventy-one patients with angiographically proven MB and 101 age- and gender-matched participants with normal coronary arteries were included in the study. Patients with acute coronary syndrome, previous cardiac surgery, known coronary artery disease, concomitant valvular disease, cardiomyopathy, heart failure, atrial fibrillation, congenital heart defects, renal or hepatic disease, malignancy, hematological disorders, and acute or chronic inflammatory disorders were excluded from this study.

\section{Angiographic analysis}

The diagnostic coronary angiograms of the patients were evaluated by the same cardiologist. Myocardial bridging was defined as systolic compression or milking of a segment of an epicardial coronary artery that courses intramurally on coronary angiography.

Table 1. Characteristics of the study population

\section{Laboratory measurements}

Venous blood samples were obtained from all participants following a fasting period of 12 hours. Biochemical parameters were determined by standard methods. Hematological parameters were analyzed by an automatic blood counter (Abbott Cell-Dyn 3700; Abbott Laboratory, Abbott Park, Illinois). The local ethics committee approved the study.

\section{Statistical analysis}

Data were analyzed with the Statistical Package for the Social Sciences (SPSS) software version 16.0 for Windows (SPSS Inc, Chicago, IL). The Kolmogorov- Smirnov test was used to verify the normality of distribution of continuous variables. Continuous variables were defined as means \pm standard deviation; categorical variables were given as percentages. The independent sample t test or the Mann- Whitney U test was used for the continuous variables and the chi-square test for categorical variables. Statistical significance was defined as $p<0.05$. Receiver operating characteristic (ROC) curve analysis was used to determine the optimum cutoff levels of $\mathrm{N} / \mathrm{L}$ ratio in association with $\mathrm{MB}$.

\section{RESULTS}

The study population consisted of $71 \mathrm{MB}$ (mean age: $51.4 \pm 11.9$ years, $80.3 \%$ male) and 101 ageand gender-matched control participants with normal coronary arteries (mean age: $50.5 \pm 11$. 3 years, $75.2 \%$ male). There were no significant differences between the groups with respect to age, gender, diabetes mellitus, hypertension, and smoking habits. The basal characteristics of the study population are listed in Table 1.

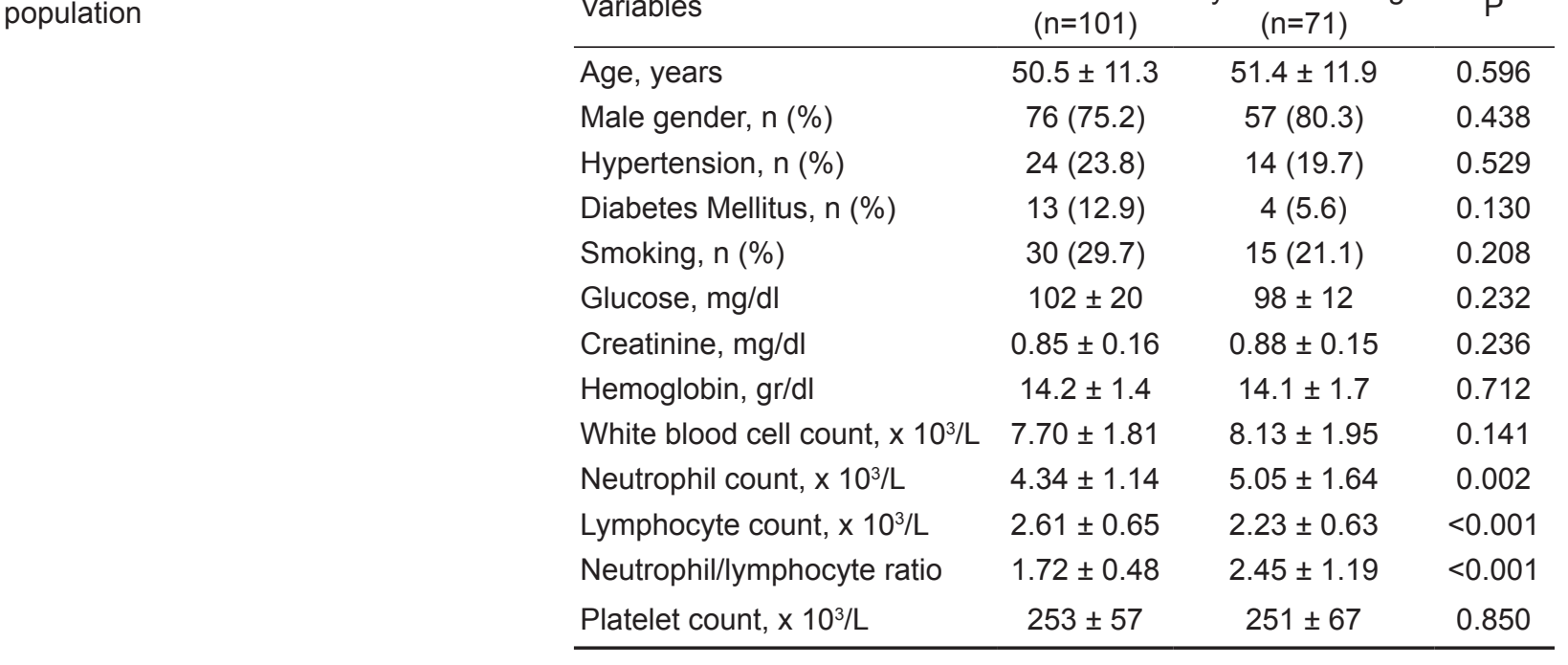


In addition, there were no significant differences between groups regarding the hemoglobin levels, platelet counts, fasting blood glucose, and creatinine levels. Compared to the control group, the NLR value was significantly higher in patients with MB $(2.45 \pm 1.19$ vs. $1.72 \pm 0.48$; $p<0.001$; Figure 1). In ROC analysis, optimum cutoff level of the NLR in association with MB presence was 1.82 with $70 \%$ sensitivity and $71 \%$ specificity (ROC area under curve: 0.733, 95\% Cl: 0.654-0.811, $p<0.001$; Figure 2).

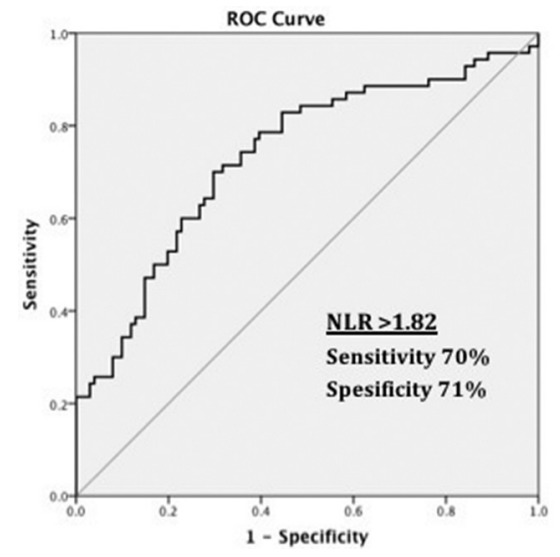

Figure 1. Box plot graphics of the neutrophil/lymphocyte ratios between myocardial bridge and control groups

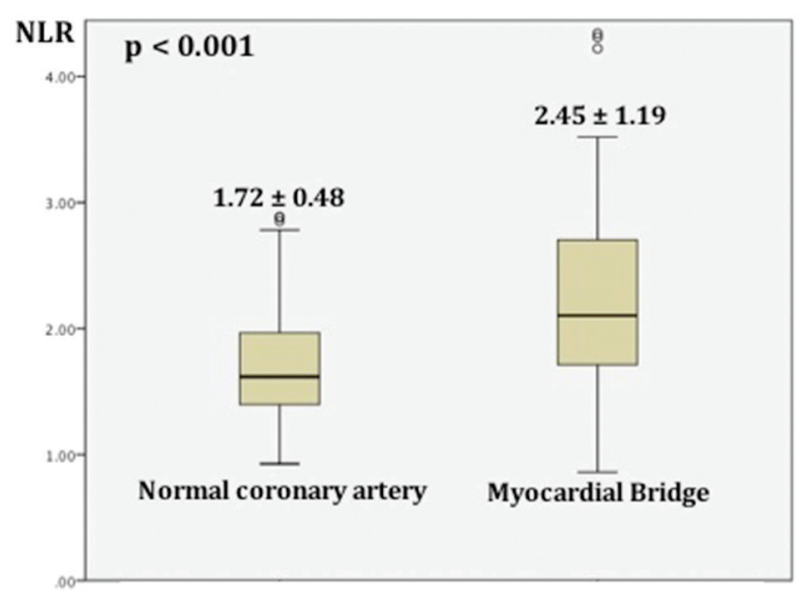

Figure 2. The receiver operating characteristic curve analysis of neutrophil/lymphocyte ratio for predicting the presence of myocardial bridge

\section{DISCUSSION}

To our knowledge, our study is the first to examine the NLR values in patients with coronary MB. We have found that patients with MB have significantly higher NLR values compared to control participants. Our results indicate that patients with MB tend to have increased inflammatory status.
Several studies have shown increased atherosclerotic plaque formation in the arterial segment proximal to MB [17-20]. As blood flow hemodynamics and atherosclerotic progression are closely related, low shear stress blood flow proximal to myocardial bridging enhances atherosclerosis by increased transfer of lipids into the intimal part of the coronary arteries [21]. However, higher shear stress within the MB causes decreased monocyte adhesion to the endothelium and a decreased lipid transfer through the artery wall resulting in the endothelium free from atherosclerosis [22-24]. Controversially, endothelial dysfunction was also demonstrated in the segments of coronary arteries beneath MB in another study [25]. This may be due to the systolic compression of the arteries causing damage to the endothelium and intima.

Neutrophil/lymphocyte ratio is a sensitive marker of systemic inflammation used as a predictor for adverse cardiovascular outcomes in atherosclerotic heart disease. In recent years, the NLR has been studied tremendously in various cardiovascular disorders. Its association with the severity of coronary artery disease, pulmonary arterial hypertension, coronary ecstasy, arrhythmias and acute coronary syndromes were demonstrated [12,14,26-30]. Increased NLR in our patients might be due to several different mechanisms. One of them might be endothelial damage caused by systolic kinking of the artery. The independent association between endothelial dysfunction and increased NLR was shown in various disorders of the body31-33. Another mechanism may be the important changes in coronary flow hemodynamics caused by MB. Blood flow-related shear stress has been asserted as a significant effect on endothelial function [34]. As atherosclerosis begins as local inflammation of arteries at sites of low shear stress, this may lead to enhanced plaque formation and progression of the coronary artery segment proximal to the MB. Ge et al. documented atherosclerotic plaque formation in the proximal to the bridged segments in $88 \%$ of the patients with MB by intravascular ultrasonography (IVUS) [20].

The main limitations of this study are relatively small sample size and cross-sectional study design. The lack of characteristics of the bridged segment is another limitation. It provides no information regarding cause or effect association between NLR and MB. The lack of IVUS use and assessment of endothelial dysfunction are other limitations.

In conclusion, our study findings demonstrated that MB is associated with elevated NLR levels. The mechanisms may be due to endothelial dysfunction 
in the $\mathrm{MB}$ region or enhanced atherosclerosis in the segment proximal to MB due to low shear stress. Although NLR was different between patients with $\mathrm{MB}$ and controls, there is still no standardized cutoff level for the NLR. Further large-scale multicenter studies are needed to confirm the clinical significance of increased NLR in patients with MB.

\section{REFERENCES}

1. Angelini P, Velasco JA, Flamm S. Coronary anomalies: incidence, pathophysiology, and clinical relevance. Circulation 2002;105:2449-2454.

2. Faruqui AM, Maloy WC, Felner JM, et al. Symptomatic myocardial bridging of coronary artery. Am J Cardiol 1978;41:1305-1310.

3. Irvin RG. The angiographic prevalence of myocardial bridging in man. Chest 1982;81:198-202.

4. Li JJ, Shang ZL, Yao M, et al. Angiographic prevalence of myocardial bridging in a defined very large number of Chinese patients with chest pain. Chin Med J (Engl) 2008;121:405-408.

5. Cicek D, Kalay N, Muderrisoglu H. Incidence, clinical characteristics, and 4-year follow-up of patients with isolated myocardial bridge: a retrospective, singlecenter, epidemiologic, coronary arteriographic followup study in southern Turkey. Cardiovasc Revascular Med 2011;12:25-28.

6. Sun JL, Huang WM, Guo JH, et al. Relationship between myocardial bridging and coronary arteriosclerosis. Cell Biochem Biophysics 2013;65:485-489.

7. Bourassa MG, Butnaru A, Lesperance J, Tardif JC. Symptomatic myocardial bridges: overview of ischemic mechanisms and current diagnostic and treatment strategies. J Am Coll Cardiol 2003;41:351-359.

8. Feld H, Guadanino V, Hollander G, et al. Exerciseinduced ventricular tachycardia in association with a myocardial bridge. Chest 1991;99:1295-1296.

9. Yano K, Yoshino H, Taniuchi M, et al. Myocardial bridging of the left anterior descending coronary artery in acute inferior wall myocardial infarction. Clinical cardiology 2001;24:202-208.

10. Micic J, Nikolic S, Savic S. Sudden cardiac death caused by complicated atherosclerosis of the anterior intraventricular branch of the left coronary artery with a myocardial muscle bridge. Srpski arhiv za celokupno lekarstvo 2003;131(3-4):173-175.

11. Thej MJ, Kalyani R, Kiran J. Atherosclerosis and myocardial bridging: Not a benign combination. An autopsy case report. Journal of cardiovascular disease research 2012;3:176-178.

12. Gibson PH, Cuthbertson BH, Croal BL, et al. Usefulness of neutrophil/lymphocyte ratio as predictor of new-onset atrial fibrillation after coronary artery bypass grafting. Am J Cardiol 2010;105:186-191.

13. Poludasu S, Cavusoglu E, Khan W, Marmur JD. Neutrophil to lymphocyte ratio as a predictor of long-term mortality in African Americans undergoing percutaneous coronary intervention. Clin Cardiol 2009;32:E6E10.

14. Gul M, Uyarel H, Ergelen M, et al. Predictive Value of Neutrophil to Lymphocyte Ratio in Clinical Outcomes of Non-ST Elevation Myocardial Infarction and Unstable Angina Pectoris: A3-Year Follow-Up. Clin Appl Thromb Hemost 2012. DOI:10.1177/1076029612465669

15. Bhat T, Teli S, Rijal J, et al. Neutrophil to lymphocyte ratio and cardiovascular diseases: a review. Exp Rev Cardiovascr Ther 2013;11:55-59.

16. Loukas $M$, Von Kriegenbergh K, Gilkes $M$, et al. Myocardial bridges: A review. Clinical anatomy 2011;24:675-683.

17. Ishikawa Y, Akasaka Y, Suzuki K, et al. Anatomic properties of myocardial bridge predisposing to myocardial infarction. Circulation 2009;120:376-383.

18. Ishikawa $Y$, Akasaka $Y$, Ito $K$, et al. Significance of anatomical properties of myocardial bridge on atherosclerosis evolution in the left anterior descending coronary artery. Atherosclerosis 2006;186:380-389.

19. Ge J, Erbel R, Gorge G, et al. High wall shear stress proximal to myocardial bridging and atherosclerosis: intracoronary ultrasound and pressure measurements. Br Heart J 1995;73:462-465.

20. Ge J, Jeremias A, Rupp A, et al. New signs characteristic of myocardial bridging demonstrated by intracoronary ultrasound and Doppler. Eur Heart J 1999;20:1707-1716.

21. Caro CG, Fitz-Gerald JM, Schroter RC. Atheroma and arterial wall shear. Observation, correlation and proposal of a shear dependent mass transfer mechanism for atherogenesis. Proceedings of the Royal Society of London. Series B, Containing papers of a Biological character. Royal Society1971;177:109-159.

22. Ishikawa $\mathrm{Y}$, Ishii T, Asuwa N, Masuda S. Absence of atherosclerosis evolution in the coronary arterial segment covered by myocardial tissue in cholesterol-fed rabbits. Virchows Archiv 1997;430:163-171.

23. Scher AM. Absence of atherosclerosis in human intramyocardial coronary arteries: a neglected phenomenon. Atherosclerosis 2000;149:1-3.

24. Chatzizisis YS, Giannoglou GD. Myocardial bridges spared from atherosclerosis: overview of the underlying mechanisms. Can J Cardiol 2009;25:219-222.

25. Kim JW, Seo HS, Na JO, et al. Myocardial bridging is related to endothelial dysfunction but not to plaque as assessed by intracoronary ultrasound. Heart 2008;94:765-769.

26. Yildiz A, Kaya H, Ertas $F$, et al. Association between neutrophil to lymphocyte ratio and pulmonary arterial hypertension. Turk Kardiyol Dern Ars 2013;41:604609.

27. Acet $H$, Ertas F, Akil MA, et al. New inflammatory predictors for non-valvular atrial fibrillation: echocardiographic epicardial fat thickness and neutrophil to lymphocyte ratio. Int J Cardiovasc Imaging 2014;30:8189. 
28. Kaya H, Ertas F, Islamoglu Y, et al. Association Between Neutrophil to Lymphocyte Ratio and Severity of Coronary Artery Disease. Clin Appl Thromb Hemost 2014;20:50-54.

29. Isik T, Ayhan E, Uyarel H, et al. Association of neutrophil to lymphocyte ratio with presence of isolated coronary artery ectasia. Turk Kardiyol Dern Ars 2013;41:123-130.

30. Erayman A, Sen N. Neutrophil-Lymphocyte Ratio and C-Reactive Protein May Be Correlated in Patients With Coronary Artery Ectasia. Angiology 2014;65:84-85.

31. Atmaca Y, Ozdol C, Turhan S, et al. The association of elevated white blood cell count and C-reactive protein with endothelial dysfunction in cardiac syndrome $\mathrm{X}$. Acta Cardiol 2008;63:723-728.
32. Demirkol S, Balta S, Unlu M, et al. Neutrophils/Lymphocytes Ratio in Patients With Cardiac Syndrome $X$ and Its Association With Carotid Intima-Media Thickness. Clin Appl Thromb Hemost 2012. DOI: 10.1177/1076029612467227.

33. Turkmen K, Tufan F, Selcuk E, et al. Neutrophil-tolymphocyte ratio, insulin resistance, and endothelial dysfunction in patients with autosomal dominant polycystic kidney disease. Indian journal of nephrology 2013;23:34-40.

34. Traub O, Berk BC. Laminar shear stress: mechanisms by which endothelial cells transduce an atheroprotective force. Arterioscl Thromb Vasc Biol 1998;18:677685. 